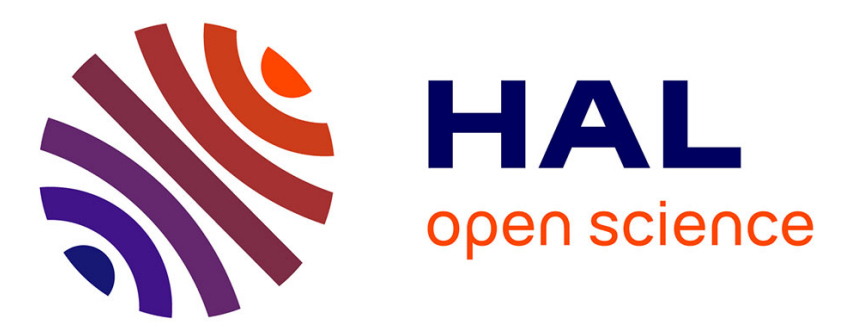

\title{
Aluminium based protective coatings produced on AISI 304 stainless steel
}

B. Brevaglieri, M. Mongelli, S. Natali

\section{To cite this version:}

B. Brevaglieri, M. Mongelli, S. Natali. Aluminium based protective coatings produced on AISI 304 stainless steel. Journal de Physique IV Proceedings, 1993, 03 (C7), pp.C7-999-C7-1002. 10.1051/jp4:19937155 . jpa-00251778

\section{HAL Id: jpa-00251778 https://hal.science/jpa-00251778}

Submitted on 1 Jan 1993

HAL is a multi-disciplinary open access archive for the deposit and dissemination of scientific research documents, whether they are published or not. The documents may come from teaching and research institutions in France or abroad, or from public or private research centers.
L'archive ouverte pluridisciplinaire HAL, est destinée au dépôt et à la diffusion de documents scientifiques de niveau recherche, publiés ou non, émanant des établissements d'enseignement et de recherche français ou étrangers, des laboratoires publics ou privés. 


\title{
Aluminium based protective coatings produced on AISI 304 stainless steel
}

\author{
B. BREVAGLIERI, M. MONGELLI and S. NATALI
}

Università degli Studi di Roma "La Sapienza", Facoltà di Ingegneria, Dipartimento di Ingegneria Chimica delle Materie Prime e Metallurgia, Via Eudossiana 18, 00184 Roma, Italy

\begin{abstract}
The diffusion of Aluminium is one of the most promising methods to build superficial coatings for stainless steel protection.

Heat treatments at $800 \mathrm{oC}$ performed on rods of AISI 304 steel, Aluminium coated by means of electrodeposition, displayed the possibility of forming intermetallic compounds. Depending on the duration of the heat treatment and on the cooling kinetics, these compounds can be continuous.

At high cooling kinetics (water cooling) a two-phase structure composed of $\gamma^{\prime}(\mathrm{Ni3} A l)$ and $\gamma$ (substitutional solid solution) is obtained.

At slow cooling rates (in furnace), a substitutional solid solution and some precipitates of $\gamma^{\prime}$ (Ni3Al) and $\beta(\mathrm{NiAl})$ can be observed.

At intermediate cooling rates (oil cooling and air cooling), only the substitutional solution and the $\gamma^{\prime}$ phase are present.

Using furnace cooling from $800 \circ \mathrm{C}$ until $500 \circ \mathrm{C}$, permanence at this temperature for $192 \mathrm{~h}$ and cooling furnace, the two-phase structure obtained is composed of the substitutional solid solution and the $\beta$ (NiAl) phase.

The existence of these phases and their composition have been reported by X-ray diffraction patterns and microanalysis.

The possibility of forming a natural composite, constituted by a hard phase of aluminides diffused in a substitutional solid solution, has an important consequence on the mechanical and protection properties of these coatings. Moreover, the diffusion of $\mathrm{Al}$ improves the adhesion of coatings.
\end{abstract}

\section{INTRODUCTION}

Diffusion coatings show a remarkable advantage over all other forms of coating, owing to the fact that the surface element moves from the coating to the substrate, gets into the crystal lattice and creates a band of "composite" material which makes surfaces resistant to hot oxidation and aggressive environments [1] [2] $[3]$.

The diffusion of Aluminium is one of the most promising methods for building surface coatings for stainless steel protection [4] [5]. Aluminium coatings are often used for Ni-based superalloys, to be used in aggressive environments that may cause severe surface degradation.

This paper deals with the behaviour of Aluminium coatings on AISI 304 stainless steel and evaluates the influence of intermetallic compounds obtained by suitable heat treatments.

As a possible application, Aluminium coatings can be used in fuel cells [6], in order to protect the stainless steel from molten carbonates attack. 


\section{MATERIAL, HEAT TREATMENTS, EQUIPMENT AND METHOD}

The experiments were carried out on a rod of AISI 304 austenitic stainless steel, whose composition ( \% at) was: $\mathrm{C} 0.041, \mathrm{Cr} 18.60, \mathrm{Ni} 8.80, \mathrm{Mn} 1.05$, Si 0.05 , Mo 0.35 .

The specimen was given an Aluminium coating about $12 \mu \mathrm{m}$ thick by electrodeposition. The coated specimens were exposed to pre-treatment at $600^{\circ} \mathrm{C}$ for $24 \mathrm{~h}$, followed by diffusion heat treatment at 800 ${ }^{\circ} \mathrm{C}$ for $24 \mathrm{~h}$, with the following cooling procedures:

a) Water cooling (microphotograph 1);

b) Oil cooling (microphotograph 2);

c) Air cooling (microphotograph 3);

d) Furnace cooling (microphotograph 4);

e) Furnace cooling until $500^{\circ} \mathrm{C}$, permanence at this temperature for $192 \mathrm{~h}$, and furnace cooling (microphotograph 5);

After the heat treatments, the flat faces of the specimens were cleaned with rubbing paper and wet polished with Aluminium powder; then they were etched with $5 \% \mathrm{H}_{2} \mathrm{SO}_{4}$ to reveal the structure of the Fe-Cr-Ni alloys. The specimens were examined under an Hitachi S 2500 Scanning Electron Microscope (SEM) and were also subjected to microanalysis (EDS), and X-ray diffraction patterns.

\section{EXPERIMENTAL RESULTS}

A substitutional solid solution and two intermetallic phases have been identified ( $\beta$ NiAl and $\left.\gamma^{\prime} \mathrm{Niz} A \mathrm{l}\right)$.

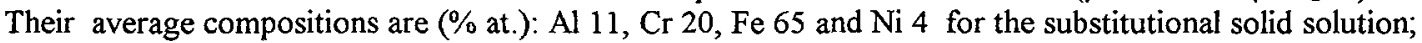
Al 37, Cr 10, Fe 37, Ni 16 for $\beta$ NiAl; Al 27, Cr 10, Fe 43, Ni 20 for $\gamma^{\prime}$ Ni3Al.

At high cooling rates (water cooling) a two-phase structure composed of $\gamma^{\prime} \mathrm{Ni}_{3} \mathrm{Al}$ and $\gamma$ (substitutional solid solution) is obtained and it can form a continuous layer of variable thickness (microphotograph 1).

At intermediate cooling rates (oil cooling and air cooling) a two-phase structure composed of $\gamma^{\prime} \mathrm{Ni}_{3} \mathrm{Al}$ and $\gamma$ (substitutional solid solution) is obtained and it forms islands of precipitates (microphotographs 2-3).

At slow cooling rates (in furnace) a substitutional solid solution and few precipitates can be observed (microphotograph 4).

By furnace cooling until $500^{\circ} \mathrm{C}$, permanence at this temperature for $192 \mathrm{~h}$, and furnace cooling only the substitutional solid solution and the $\beta \mathrm{NiAl}$ phase are present (microphotograph 5).

The intermetallic phases differ as regards composition and morphology, forming either a continuous layer or islands of precipitates scattered in the substitutional solid solution.

\section{DISCUSSION OF THE RESULTS}

It is possible to point out, that at slow cooling rates only few precipitates can be observed, as is shown in microphotograph 4.

When cooling kinetics are faster, precipitates increase in size and in number as they go through the different types of cooling treatments: from the furnace cooling to air, oil and water cooling.

This is owing to the fact that precipitates always form [7], but the slow cooling kinetics (furnace cooling) permits them to dissolve almost completely, while a faster cooling kinetics ( water cooling) does not permit the precipitates to dissolve themselves [8].

The dissolution of these precipitates can be justified by supposing the presence of an eutectoidic transformation composed of $\beta, \gamma^{\prime}$ and $\gamma$.

$\gamma$ is the substitutional solid solution, $\beta$ is the intermetallic compound $\mathrm{NiAl}$ and $\gamma^{\prime}$ represents $\mathrm{Ni}_{3} \mathrm{Al}$. 
The presence of a substitutional solid solution $\gamma$ and of the two intermetallic compounds $\gamma^{\prime}$ and $\beta$ can be justified by a pseudobinary diagram ( $\mathrm{Al} \%, \mathrm{Ni}-\mathrm{Cr}-\mathrm{Fe} \%$ ), as is shown in fig. 1 .

The $\gamma^{\prime}$ phase, limited on the upper side by a peritectoidic transformation and on the lower side by an eutectoidic one, has been confirmed in other aluminium alloy diagrams (Al-Mn, Al-Fe ( $\varepsilon$ ), Al-Ru, Al-To). At high cooling rates from $800{ }^{\circ} \mathrm{C}$ a two phase structure composed of $\gamma^{\prime}\left(\mathrm{Ni}_{3} \mathrm{Al}\right.$ ) and $\gamma$ (substitutional solid solution) is obtained (microphotographs 1-2-3).

At slow cooling rates (furnace cooling) the structure becomes almost completely a monophasic one because the substitutional solid solution and only few precipitates of $\gamma^{\prime} \mathrm{Ni}_{3} \mathrm{Al}$ and $\beta \mathrm{NiAl}$ are present.

These two compounds have been found by $\mathrm{X}$-ray diffraction patterns and they have been confirmed by other authors [9]; this is owing to the fact that $\gamma^{\prime} \mathrm{Ni}_{3} \mathrm{Al}$ is completely dissolved, through furnace treatment, while $\beta$ NiAl forms but it does not increase (microphotograph 4).

At faster cooling rates (air and oil), only the substitutional solid solution $\gamma$ and the $\gamma^{\prime} \mathrm{Ni}_{3} \mathrm{Al}_{\text {are }}$ present because the dissolution kinetics of $\gamma^{\prime} \mathrm{Ni}_{3} \mathrm{Al}$ does not permit its complete dissolution and, moreover, the formation kinetics of $\beta \mathrm{NiAl}$ does not permit ever its formation .

Using furnace cooling, followed by $500^{\circ} \mathrm{C}$ for $192 \mathrm{~h}$ a two-phase structure is obtained. This is composed of the substitutional solid solution and the $\beta$ NiAl phase: $\gamma^{\prime} \mathrm{Ni}_{3} \mathrm{Al}$ is completely dissolved, while $\beta \mathrm{NiA} J$ forms and increases (microphotograph 5). The composition of $\beta \mathrm{NiAl}$ has been confirmed in the ternary phase diagram in fig. $2(\gamma)$ [10] [11].

The solid substitutional solution and the $\gamma^{\prime} \mathrm{Ni}_{3} \mathrm{Al}$ phase have been found in the same diagram.

\section{CONCLUSION}

A substitutional solid solution and two intermetallic phases have been identified $\beta \mathrm{NiAl}$ and $\gamma^{\prime} \mathrm{Ni}_{3} \mathrm{Al}$ by suitable heat treatments.

These heat treatments have been carried out at different temperatures, duration and cooling kinetics.

It was possible to form a surface natural composite and to check its composition by suitable heat treatments.

The natural composite, formed by hard-phase aluminides dispersed in a substitutional solid solution has an important consequence on the mechanical strength and corrosion resistance of these coatings.

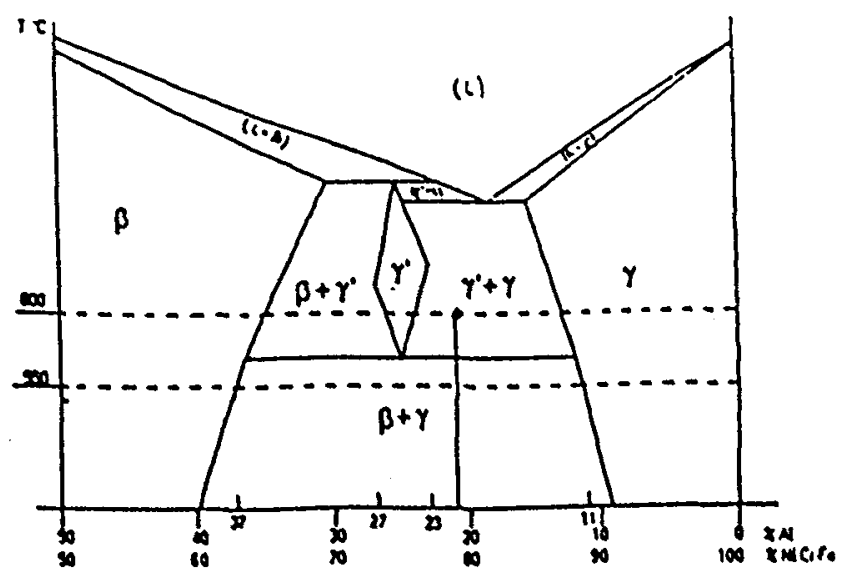

Fig. 1

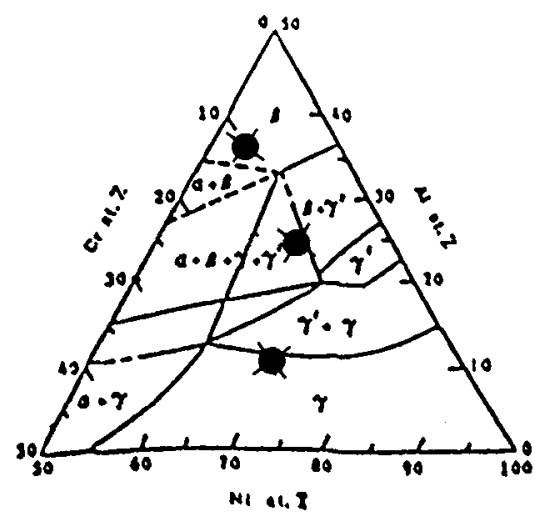

Fig. 2 


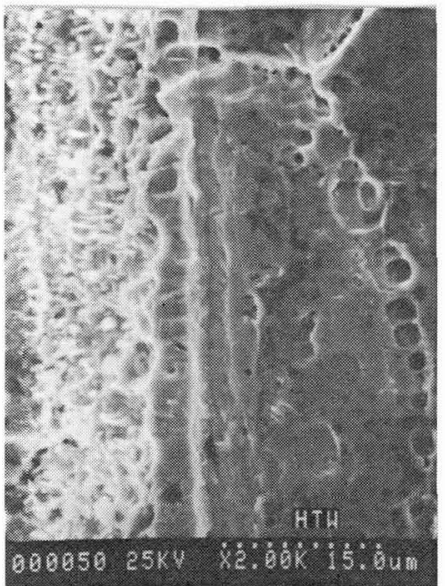

microphotograph 1

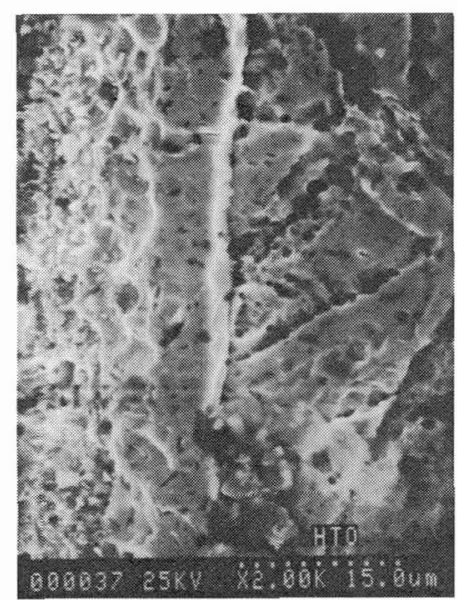

microphotograph 2

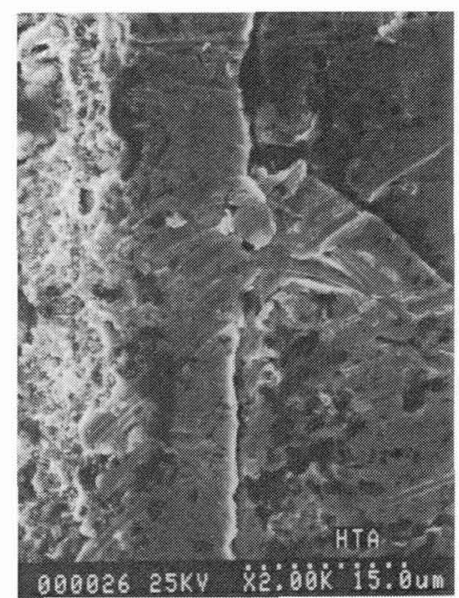

microphotograph 3

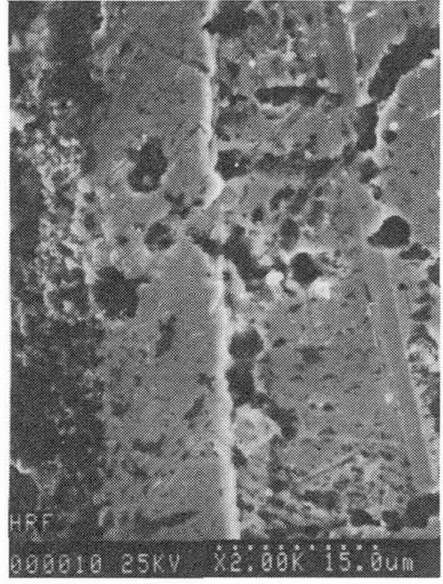

microphotograph 4

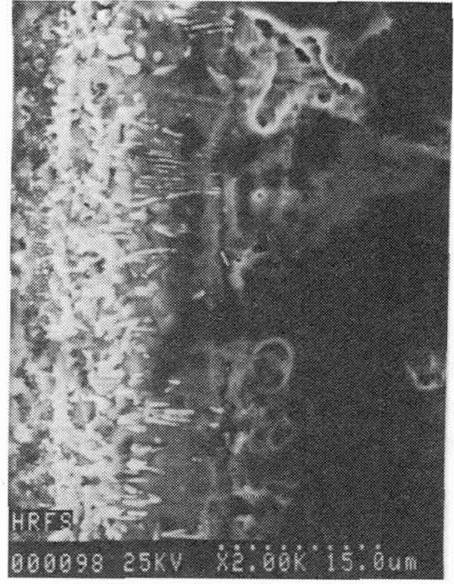

microphotograph 5

\section{REFERENCES}

[1] G. GAUJE' AND R. MORBIOLI, High Temperature Protective Coatings, Subhash C. Singhal Ed, (1982) 13.

[2] GOWARD, Journ of Metals 10 (1970) 31.

[3] G. H. MARIJNISSEN, High Temperature Protective Coatings, Subhash C. Singhal Ed. (1982) 27.

[4] CHAPMAN, N.R., B.MICKLETWAITE AND G.A. PICKUP, Anticorrosion 17 (1970) 10.

[5] DREWETT, Anticorrosion 16 (1970) 10.

[6] R.W. CARLING, R.W. BRADSHAW, AND R.W. MAR, High Temperature Protective Coatings, Subhash C. Singhal Ed. (1982) 261.

[7] N.V. BANGARU, R.C. KRUTENAT, J.VAC. SCI. TECNOL. B 2 (1984) 806.

[8] A. DESESTRET ET J.CHARLES, Les Aciers Inoxidables, Les Edition de Phisique (1990) 631.

[9] M. E. EL-DAHSHAN, High Temperature Protective Coatings, Subhash C. Singhal Ed. (1982) 206.

[10] P.NASH, M. F. SINGLETON, AND J. L. MURRAY, Alloy Phase Diagram (1991) 2-49.

[11] V. A. RAVI, P.A. CHOQUET AND R.A. RAPP, Oxidation of High-Temperature Intermetallic, Tony Grobstein And Joseph Doychak (1988) 127. 